\title{
Pastorale begeleiding van die self-mutileerder
}

\author{
Authors: \\ Wentzel C. Coetzer ${ }^{1}$ \\ Affiliation: \\ ${ }^{1}$ School of Ecclesiastical \\ Sciences, Potchefstroom \\ Campus, North West \\ University, South Africa \\ Correspondence to: \\ Wentzel Coetzer \\ Email: \\ wentzel.coetzer@nwu.ac.za \\ Postal address: \\ PO Box 19320, Noordbrug \\ 2522, South Africa \\ Dates: \\ Received: 09 Mar. 2011 \\ Accepted: 28 July 2011 \\ Published: 29 Nov. 2012 \\ How to cite this article: \\ Coetzer, W.C., 2012, \\ 'Pastorale begeleiding van \\ die self-mutileerder', In die \\ Skriflig/In Luce Verbi 46(2) \\ 2012, 9 pages. http://dx.doi. \\ org/10.4102/ids.v46i2.69
}

(C) 2012. The Authors.

Licensee: AOSIS

OpenJournals. This work

is licensed under the

Creative Commons

Attribution License.
In hierdie artikel het dit geblyk dat die toenemende voorkoms van self-mutilering onder jongmense in talle gevalle as uitlaatklep gedien het vir opgeboude druk en nie soseer as ' $n$ selfmoordpoging nie. Heel dikwels was dit 'n uitvloeisel van mishandeling en/of seksuele misbruik en die persoon het dan hierdie metode gebruik om van innerlike pyn ontslae te raak. Gevoelens van alleenheid, 'n behoefte aan beheer, 'n behoefte om net íéts te voel, asook 'n behoefte om die self te straf, kon ook 'n rol gespeel het. Die gesinsklimaat was oor die algemeen van besondere belang. Hierdie probleem het aan pastorale beraders en aan die kerk ' $n$ besondere uitdaging gebied deur onder andere veel meer op die probleem van pyn, asook die hantering daarvan te fokus. Dit het verband gehou met die feit dat ontkenning in die verlede ' $n$ groot rol gespeel het in sekere kerklike kringe en ook binne sekere gesinne. As deel van ' $n$ pastoraal-terapeutiese strategie in die begeleiding van die self-mutileerder kon aspekte soos die identifisering van die rol van leuens, die benutting van oplossings uit die verlede, vergifnis, nagmaal, gebed en meditasie gevolglik uiters belangrike komponente van die helingsproses gevorm het. Pastorale beraders sal hulleself ten volle op die hoogte moet bring van die verskynsel van self-mutilering ten einde in staat te wees om werklik te kan help.

Pastoral guidance for the self-mutilator. In this article it seemed that the increase in the occurrence of self-mutilation among young people in many cases served as a pressure-relief valve and not a suicide attempt as such. It was very often the outcome of ill-treatment and/ or sexual abuse and the person used this method to get rid of the inner pain. Feelings of aloneness, a need to be in control, a need to feel at least something and a need to punish the self could also have played a role. The family climate was generally very important. This provided a special challenge for pastoral counsellors as well as the church by, among others, focussing more on the problem of pain and how to handle it. This was relevant to the fact that denial had played a significant role in certain church circles as well as within some families. As part of the pastoral-therapeutic strategy in helping the self-mutilator, aspects such as identifying the role of lies, the use of solutions from the past, forgiveness, the Lord's Supper, prayer, and meditation were therefore very important components in the healing process. Pastoral counsellors would have to be well informed about the phenomenon of self-mutilation in order to be able to be of real help.

\section{Inleiding}

$\mathrm{Al}$ meer jongmense raak by die probleem van self-mutilering betrokke (soos wat deur statistieke in ' $n$ volgende paragraaf aangedui sal word) en dit raak uiteraard ook kerklike lidmate. Die psigiater Frank Minirth (Minirth \& Byrd 1994:22) toon aan dat 42\% van diegene wat hulp soek eerstens na hulle leraar sal gaan. Daarom is dit belangrik vir die pastoraat om toegerus en op hoogte te wees van 'n probleem soos self-mutilering.

\section{Fokus en metodologiese vertrekpunt}

In hierdie artikel word die volgende probleemstelling ondersoek: In watter mate kan pastorale begeleiding ' $n$ terapeutiese rol vervul aan persone wat vasgevang is in self-mutilering? In dié verband word daar gefokus op die aktualiteit, omvang asook redes waarom jongmense hulleself mutileer. Tekens wat op 'n probleem sou kon dui, riglyne vir'n moontlike behandelingsprogram, asook ' $n$ aantal pastorale perspektiewe word ook aan die orde gestel. Aangesien dit belangrik is dat pastorale beraders begrip sal hê vir die breëre psigolosiese raamwerk waarbinne die problematiek van self-mutilering soms ingebed is, is die vertrekpunt van hierdie artikel dan ook 'n psigologies-georiënteerde pastorale benadering. 


\section{Aktualiteit en statistieke}

Die tema van self-mutilering (self-snyding) as verslawende gedrag het gedurende die afgelope dekade in al groter mate die onderwerp van ernstige studie en navorsing geword en uiteindelik ' $n$ gevestigde tema geraak binne die literatuur (Aizenman \& Jensen 2007:27; Gratz \& Roemer 2008:97; Penner 2008:14).

Hierdie tipe gedrag gaan in teen die mens se diepste instink vir selfoorlewing en die vermyding van pyn. Horning (2010:107) beskryf die verhaal van 'n 22-jarige student, Hester, wat as kind gemolesteer is, en vir wie die trek van 'n lemmetjie oor haar arms en lieste totdat dit bloei, die gevoel van ware lewe geïmpliseer het:

I began at 14, to take away my numbness - I know it must sound nuts but I think I'd anaesthetized myself against life, and feeling something was better than feeling nothing. (Horning 2010:107)

Volgens Penner (2008:9), 'n veteraan-jeugwerker wat reeds 30 jaar in sy privaatpraktyk intens betrokke is by die begeleiding van emosioneel verwonde jongmense en hulle gesinne, het meeste volwassenes geen idee hoe ernstig die probleem van self-snyding geword het binne die huidige generasie nie. Clark en Henslin (2007:10, 23) maak selfs die stelling dat die oorgrote meerderheid van professionele persone binne die veld van geestesgesondheid nie ten volle begrip het vir die kompleksiteit van die verskynsel van self-mutilering nie. Wat hierdie probleem verder kompliseer, gesien vanuit ' $n$ diagnostiese oogpunt, is dat, afgesien van die omvang van die probleem, self-mutilasie bloot beskryf word as ' $n$ simptoom wat verband hou met stres of grenspersoonlikhede, en nie 'n spesifieke siekte nie. Terminologie wat hiermee verband hou, ontbreek ook grootliks in mediese woordeboeke (Hicks \& Hinck 2008:409).

Die boek, Cutting: Understanding and overcoming self-mutilation, deur Steven Levenkron (1999), was een van die eerste boeke wat spesifiek gefokus het op die probleem van selfmutilering. Levenkron was in daardie stadium oortuig dat daar in die algemeen kennis geneem moet word van 'n verskynsel wat besig was om deel te word van die NoordAmerikaanse jeugkultuur. Levenkron se boek word steeds as 'n standaardteks beskou betreffende insig in die probleem van self-mutilasie (Penner 2008:18). In die inleiding tot sy boek het Levenkron bereken dat self-mutilasie 'n probleem is vir ongeveer een uit elke 250 tienermeisies in die Verenigde State van Amerika ('n bietjie meer as 'n halfpersent). Hy beweer verder dat self-mutilasie in daardie stadium nie ' $n$ probleem was vir seuns nie.

In 2006 is belangrike bevindinge egter gepubliseer deur die universiteite van Princeton en Cornell betreffende 'n omvangryke studie wat gedoen is onder hulle studente (Whitlock 2010). Hierdie studie, waarin meer as 3000 studente betrek is, het aangedui dat ongeveer $17 \%$ (een uit vyf meisies, en een uit sewe mans) self-mutilasie toegepas het op die een of ander stadium in die verlede. Hierdie resultate verteenwoordig 'n toename van epidemiese omvang, vergeleke met Levenkron (1999) se syfers agt jaar tevore. Die respondente het meestal ook aangedui dat die gebeure in die geheim plaasgevind het. Gevolglik kan die afleiding gemaak word dat hierdie statistieke slegs die seekoei se oortjies is (Penner 2008:18; Whitlock 2010).

Volgens Whitlock (2010) het $12-24 \%$ jongmense in die ouderdomsgroep van 14 tot 25 self-mutilasie beoefen. Volgens Gratz en Roemer (2008:14) is die persentasie onder hoërskoolkinders 14-21\% en onder studente styg dit na 17-41\%. Sim, Adrian, Zeman, Cassano en Friedrich (2009:76) dui aan dat meer as $60 \%$ van adolessente wat in psigiatriese eenhede gehospitaliseer is, betrokke was by opsetlike self-mutilering.

\section{Definiëring en terminologie}

Verskillende terme word gebruik in die beskrywing van selfdestruktiewe gedrag: selfgerigte geweld, selfmisbruik, selfbenadeling, selftoegediende geweld, selfbesering, self-sny, selfmutilasie, simboliese verwonding, selfaanval, outo-aggressie, deliberate self-harm syndrome en self-injurious behavior syndrome (Pattison \& Kahan 1983:867; Clark \& Henslin 2007:21; Penner 2008:31; Ryan, Allen Heath, Fischer \& Young 2008:238). Opsommend gestel, is self-mutilasie ' $n$ poging om jou emosionele toestand te verander deur aan jou eie liggaam fisiese skade te berokken sonder die bedoeling om selfmoord te pleeg. Self-snyers probeer dus om hulle gevoelens te verander deur hulleself seer te maak met oogmerke wat nie sosiaal erken en gesanksioneer word nie (Aizenman \& Jensen 2007:29; Penner 2008:32; Lax 2010:5; Whitlock 2010). Hulle poog om op hierdie wyse psigologiese stres te laat afplat (Shamos 2007:255). Holm en Severinsson (2010:52) beskryf hierdie aksie as ' $n$ poging om 'n toestand van depersonalisasie te beëindig. Scholtz en Fiedeldey (1994:138) gebruik die volgende definisie as basiese vertrekpunt: 'Selfmutilation is a direct, physically damaging form of self-harm generally of low lethality, often repetitive in nature, and commonly employing multiple methods.'

Hicks en Hinck (2008:409) plaas 'n belangrike klem met die volgende definisie: 'Self-mutilation is defined as the intentional act of tissue destruction with the purpose of shifting overwhelming emotional pain to a more acceptable physical pain.'

Van die mees algemene vorme van self-mutilasie is sny, brand, die uittrek van hare, jouself te slaan of jouself met iets te slaan, jouself te krap, die breek van eie bene, of die opsetlike toedien van 'n oordosis van enigiets wat skadelik is vir die liggaam (Harmless 2010b; Whitlock 2010).

\section{Moontlike oorsake vir self-mutilasie}

Daar is nie ' $n$ simplistiese antwoord op die vraag na waarom jongmense hulleself mutileer nie. Die motivering daaragter is nie altyd klinkklaar nie. Meestal is dit 'n verskeidenheid aspekte. Die mees algemene redes is oorweldigende emosies, depressie, angs, pyn en ontnugtering (Kern 2007:33). Die volgende verskeidenheid van moontlikhede sou egter deurgaans in gedagte gehou kan word. 


\section{'n Uitlaatklep vir opgeboude druk (pressure relief valve)}

Self-mutileerders beskryf die proses van self-mutilering op verskillende wyses, maar ten diepste gaan dit om ' $n$ uitlaatklep vir opgeboude innerlike emosionele spanning, (Penner 2008):

I do it because I can't get mad at people, at least on the surface. Anytime someone acts mean to me or anything, I just get sad. But it all wells up ... and then all of a sudden I just sorta snap. Then I run upstairs as fast as I can and cut until everything goes away. (bl. 78)

Self-toegediende pyn is dus vir talle ' $n$ kragtige, effektiewe, verslawende en onmiddellike manier om spanning te verlig. Fisiese pyn, die visuele stimulasie van bloed (of bv. brandwonde) en die gepaardgaande gevoelens van verligting dien as afleiding vanaf emosies en omstandighede wat hulle nie kan, of wil konfronteer nie (Clark \& Henslin 2007:46; Swannell, Martin, Scott, Gibbons \& Gifford 2008:102), 'They temporarily inflict physical pain to take away other emotional pain' (Gregston 2006:43).

\section{Die uitvloeisel van mishandeling en/of seksuele misbruik}

Hicks en Hinck (2008:410) toon vanuit hulle navorsing aan dat die enkele mees algemene eienskap van self-mutileerders 'n geskiedenis van seksuele misbruik tydens die kinderjare is (vgl. ook Aizenman \& Jensen 2007:29). Penner (2008:95), sowel as Whitlock (2010:5), bevestig hierdie sterk korrelasie, maar waarsku egter teen die foutiewe aanname dat elke selfmutileerder noodwendig seksueel misbruik is.

\section{Die persoon het ' $n$ behoefte aan ' $n$ metode om van pyn ontslae te raak}

Sommige persone gee uiting aan innerlike pyn deur trane of aggressie, of deur hulle toevlug te neem tot die een of ander substans. Ander gee egter uiting deur hulleself te sny en te verwond:

There are times when I just hurt too bad - too deep for tears - so I cut and it lets out some of the hurt. It's like when you see the blood flowing out, the pain and fear are flowing out with it ... I need to see the bad feelings bleed away ... I couldn't cry, and bleeding was a different form of crying. (Clark \& Henslin 2007:47)

\section{Gevoelens van alleenheid}

Self-mutilering word soms ingespan om gevoelens van alleenheid te hanteer. Dit kan wees nadat ouers deur ' $n$ egskeiding is, nadat die persoon self deur 'n egskeiding is, nadat iemand aan die dood afgestaan is, of verwerping deur 'n portuurgroep (Kern 2007:33; Clark \& Henslin 2007:51; Harmless 2010a).

\section{'n Behoefte aan beheer en kontrole}

Vir adolessente wat die wêreld moontlik as chaoties en vyandig mag beleef, kan self-mutilering ' $n$ wyse wees om outonomie te vestig. Hulle raak gevolglik hierby betrokke in ' $n$ poging om onbeheerbare omstandighede te probeer beheer
(Kern 2007:34; Hicks \& Hinck 2008:411; Whitlock 2010), 'I felt totally calm and rational when I did it, like I was finally in control of my life. And the whole experience was such a relief' (Freeman 2003).

\section{Daar is ' $n$ behoefte om net iets te voel}

Sommige sê hulle sny hulleself ten einde te voel dat hulle nog lewe en dat alles ' $n$ werklikheid is. Om pyn te ervaar, is dan ook soms beter as om niks te ervaar nie; hierdeur vind daar as 't ware weer ' $n$ konneksie met die realiteit plaas (Swannel, Martin, Scott \& Gifford 2008:102).

\section{'n Manier om hulleself te straf}

Persone is van mening dat hulle nooit vergewe sal kan word vir persoonlike mislukkings in die verlede nie en dat hulle hulleself gevolglik daarvoor moet straf (Gregston 2006:39; Kern 2007:34).

\section{Die rol van die gesinsklimaat}

\section{Verbrokkeling van gesinsbande}

Adolessente ly emosionele skade as gevolg van 'n gebrek aan intieme tyd saam met hulle ouers. Vanweë finansiële redes word albei ouers in talle gesinne verplig om te werk. Mense raak ook al meer geïsoleer van hulle uitgebreide families. Die groter aantal enkelouers, asook stygende egskeidingsyfers dra ook by tot ' $\mathrm{n}$ terminering van gesinsverbintenisse (Selekman 2002:7; Sim, Adrian, Zeman, Cassano \& Friedrich 2009:86).

\section{Te min tyd vir kinders}

Selekman (2002:7) wys op die resultate van 'n studie betreffende adolessente wat aantoon dat die betrokke groep se moeders gemiddeld agt minute per dag betrokke was in gesprekvoering met hulle tieners, en die pa's gemiddeld drie minute. Verder blyk dit dat ouers tans $40 \%$ minder tyd deurbring saam met hulle kinders as 30 jaar gelede.

\section{Kontrole en manipulering}

Pogings deur ouers om deur kontrole en manipulasie 'n probleem-tiener te beheer, intensifiseer gewoonlik die kompleksiteit van die probleem (Yip 2006:139).

\section{Negatiewe invloede van 'n outoritêre pa}

Selekman (2002:48) wys op die negatiewe invloed van 'n outoritêre pa in sommige self-mutileerders se huise. Wanneer dit kom by enige besluitneming, is dit die pa wat alleenseggenskap het. In sommige gevalle sal aggressie of ander vorme van intimidasie gebruik word om veral die vroulike stemme in die gesin stil te maak (vgl. ook Yip 2006:142; Sim et al. 2009:86).

\section{Kommunikasieprobleme in ouerhuis}

Kern (2007:34) maak die stelling dat 'n groot aantal jongmense wat hulleself sny ten einde beheer oor emosies te verkry, kommunikasieprobleme tuis ervaar. Die gebruik van ouerlike swye (parental silence) kan dan ook baie doeltreffend 
wees om die stem te doof van 'n adolessente meisie wat behoefte het aan erkenning, bevestiging (validation) en meer outonomie (Selekman 2002:18). In dié verband maak Clark en Henslin (2007:51) die stelling dat talle jong vroue vandag hulle liggame as kennisgewingborde beskou. Die manier waarop hulle aantrek, hulleself grimeer en/of hulle liggame modifiseer, dra dikwels 'n boodskap oor waarin dit om veel meer as net smaak of artistieke voorkeur gaan. 'Self-inflicted violence makes audible their silent shrieks within' (Whitlock 2010; Selekman 2010). Welsh (2004), wat vir 30 jaar onderrig gegee het aan 'n hoërskool, vertel van 'n gesprek met 20 hoërskoolseuns en -meisies wat almal betrokke was by self-mutilering. Uit die gesprek het geblyk dat in die meeste gevalle die verhoudings tuis met hulle ouers haglik was en dat dit grootliks bygedra het tot emosionele laagtepunte, wat dan weer self-mutilasie tot gevolg gehad het.

\section{Die rol van geïnternaliseerde leuens}

Kern (2007:48) vertel die verhaal van Jackie, 'n selfmutileerder. Een van die bydraende faktore hiertoe was ' $n$ verkragting vroeër in haar lewe en 'n polisieman haar daarna nie wou glo nie. Haar pa het haar boonop geroskam oor die tipe rok wat sy aangehad het en geen empatie getoon nie. Sy het beleef dat die hele situasie en almal betrokke die boodskap uitgeskreeu het: 'You deserve to be treated this way. Bad things happen to bad people.You're not worth anything.'

Sy het gevolglik probeer om hierdie boodskap stil te maak deur dwelms, seks, alkohol, self-mutilering en self-isolasie. Die leuen dat sy nie goed genoeg is nie, het gaandeweg diep ingeëts geraak in haar psige. Sodanige geïnternaliseerde leuens word verder versterk deur die aanwesigheid van die dinamiek van familiegeheime wat, volgens Selekman (2002:20), heel dikwels figureer binne gesinne van selfmutileerders. Die self-mutileerder kan byvoorbeeld met die geheim van molestering deur ' $\mathrm{n}$ gesinslid worstel, of per toeval afkom op bedrog wat een gesinslid pleeg teenoor ' $n$ ander een. Met verloop van tyd eis die geheimhouding sy tol in terme van depressiewe gevoelens en angs, wat weer die moontlikheid van self-mutilering verhoog (Kern 2007:49).

Hierdie tipe situasie hou heel dikwels ook verband met 'n milieu waar emosionele eerlikheid nie geduld word nie. Gaandeweg gee dit dan aanleiding tot negatiewe gevoelens wat onder die oppervlak septies raak en in so 'n mate intensifiseer dat dit uiteindelik op die een of ander wyse geventileer móét word:

In our household we have to be brave. Crying is not allowed. My father has a very short temper and if you make noise that will annoy him like crying, he gets mad. I'm not incapable of crying, I just can't. For my sake it's best that I don't. I do it [cutting] to stop thinking so that I have something else to occupy my mind in times of pain. I cry through the blood; my body cries for me. (Penner 2008:22)

\section{Emosionele bloedskande}

Die frase emosionele bloedskande word onder meer gebruik deur Hemfelt, Minirth \& Meier (2003:56). Selekman (2002:8) gebruik in dié verband die term parentification. Hierdie proses sou plaasvind wanneer ouers misluk in die vervulling van ouerlike rolle as gevolg van siekte, probleme rondom substans misbruik of verhoudings wat skipbreuk gely het. In sommige gevalle sal ' $\mathrm{n}$ kind (the parentified child) dan die rol begin vervul van ' $n$ tipe surrogaat-ouer, as terapeut vir 'n enkelouer dien, of ingetrek word as skeidsregter of fasiliteerder in die ouers se huwelik. Die grootste tragedie van so ' $n$ proses is die prysgewing van so ' $n$ jongmens se kinderjare.

\section{Uiting aan onverwerkte trauma}

In haar boek, A bright red scream: Self-mutilation and the language of pain, verwys Strong (1998) na intensiewe onderhoude met 50 persone wat self-mutilering toepas, waarin hulle hulle verhale vertel. Sy verweef hierdie verhale met opsommings van relevante navorsing, asook kommentaar deur kliniese outoriteite. 'n Dominante tema dwarsdeur hierdie beskrywing is dat self-mutilering ' $n$ stem gee aan ongemetaboliseerde kinderjare-trauma. Yip (2006:134) verwys ook binne dieselfde verband na die rol van interpersoonlike konflik, asook ongelukkige kinderjare en trauma.

Swenson (1999:1234) wys egter op die resultate van sekere navorsing wat aantoon dat in 50\% gevalle van selfmutilering daar nie noodwendig ' $n$ trauma-geskiedenis was nie. In berading sal dié aspek dus ook in gedagte gehou moet word.

Clark en Henslin (2007:108) haal navorsing aan van dr Bessel van der Kolk, 'n outoriteit op die gebied van posttraumatiese stres, wat daarop dui dat 'n ooraktiewe amigdala en 'n onderaktiewe hippo-kampus in die brein verhoed dat traumatiese gebeure analities en beheers geprosesseer word. In plaas dan daarvan om onaangename omstandighede as pyn van die verlede te beskou, herbeleef sommige traumaslagoffers die gebeure telkens asof dit steeds voortgaan en steeds ' $n$ gevaar is. Hierdie patroon word ook dikwels waargeneem by self-mutileerders, en as gevolg van gebeure in die verlede is stresvlakke voortdurend tot die maksimum verhoog. Om uit hierdie situasie te probeer wegbreek, word daar dan gebruik gemaak van gemoedsveranderende substanse (soos alkohol, pille of kos), of gemoedsveranderende gedrag (soos promiskue seks of self-mutilasie) ten einde alle gevoelens in hulle denke en liggame uit te blokkeer.

\section{Pynvolle interpersoonlike verhoudinge}

Holm \& Severinsson (2008:33) haal verskillende studies aan waarin verskillende aspekte rakende interpersoonlike verhoudinge beklemtoon word wat uiteindelik bydraende faktore is tot self-mutilering. By verskeie van die self-snyers was daar situasies wat aanleiding gegee het tot gevoelens van verwerping en emosionele stres. 


\section{Moontlike simptome wat aanduidend van self-mutilering is}

Die volgende lys van gedragswyses, simptome of tekens sou kon dui op 'n moontlike probleem betreffende selfmutilering (Pattison \& Kahan 1983:867; Gregston 2006:63; Clark \& Henslin 2007:119; Penner 2008:49; Selekman 2010:51; Whitlock 2010):

- Onverklaarbare littekens, snye, krapmerke of brandmerke op die arms of bobene is die mees algemene plekke op die liggaam waar self-mutilering toegepas word. Persone wat self-mutilering toepas dra langmouhemde of langbroeke, selfs wanneer die weer of die geleentheid iets gemakliker sou vereis en hulle hoogste prioriteit is om hulle geheim te bedek, ondanks eie gemak.

- 'n Verskeidenheid van armbande kan by geleentheid bloot ter versiering wees. Self-mutileerders sou egter 'n verskeidenheid van armbande kon dra ten einde die snymerke en letsels op hulle arms te verberg.

- Gebreekte weggooibare lemmetjies wat in skeermesse gebruik word, is waarskynlik die maklikste bekombare skerp voorwerp in meeste huise.

- 'n Versameling van skerp voorwerpe:

Carrying a prized knife at all times gives the self-injurer a sense of control - if something should go emotionally wrong, he or she has the option of taking care of it immediately. (Penner 2008:51)

- Bebloede watte, sneesdoekies of toiletpapier, of bloed op handdoeke, waslappe, ensovoorts.

- Indien hierdie verskynsel geneig is om 'n gereëlde patroon te word, kan dit ' $n$ rooilig wees. Gee veral aandag aan bloedmerke wat in die vorm van 'n lyn is.

- Eerstehulp voorraad of antiseptiese salwe langs die bed of in die badkamer.

- Arms en veral gewrigte wat gekrap en gevryf word. Snye is gewoonlik jeukerig wanneer dit genees. 'n Kombinasie van lang moue en konstante vryf en krap van die arms sou kon dui op self-mutilering.

- As gevolg van die intense emosies wat dikwels die dryfkrag is agter self-mutilerende gedrag (emosionele roller coaster), asook die intense en onmiddellike verligting wat gepaard gaan met 'n sny-episode, is dit nie ongewoon om ekstreme emosionele siklusse by self-mutileerders waar te neem nie.

- 'n Onwilligheid om deel te neem aan sekere aktiwiteite: dit sal tipies gaan oor aktiwiteite waar die liggaam in mindere mate bedek is, soos swem, of oefen in 'n gimnasium.

- Dwelm- en alkoholmisbruik blyk algemene saamlopers te wees van opsetlike selfbenadeling.

- Ongereelde slaapgewoontes.

- Donker gedagtes en kommentaar.

- Persone wat hulleself terugtrek en isoleer van ander.

- 'n Houding van futiliteit wat in hulle gesprekke te bespeur is.

- Gebrek aan eetlus.

- Gebrek aan lewenslus.

- 'n Algemene gebrekkige respons van hulle kant af.

- Intense weerstand teen 'n roetinebesoek aan 'n huisdokter of om vir mediese hulp te gaan.
- In die persoon se vriendekring is daar persone wat selfmutilering toepas.

- Die taalgebruik van die persoon dui voortdurend op 'n lae eiewaarde, asook die behoefte om gestraf te word.

- Die gesin en/of familie het 'n geskiedenis van geestesproblematiek.

\section{Belangrike pastorale riglyne vir die begeleidingsproses van die self- mutileerder}

Kern (2007:35) wys op die feit dat daar nie altyd in die kerk genoeg oor pyn gepraat word nie en dat dít weer aanleiding gee tot 'n mate van ontkenning betreffende eie wroeging en worsteling. Penner (2008) maak in dié verband die volgende krities belangrike uitspraak betreffende die verskynsel van self-mutilering onder kerklike jongmense:

But our finding ways to share that hope and healing with hurting teenagers has to begin by recognizing that this brokenness exists in our midst. There may very well be kids in our congregations - kids of fine-looking families - who are choosing to deal with their pain in selfdestructive ways. (bl. 10)

Dit is dus belangrik dat die pastoraat ook op die probleem van self-mutilering sal fokus, en vervolgens 'n aantal praktiese riglyne in die verband. Die keuse van hierdie riglyne vind op 'n eklektiese wyse plaas (Meier, Minirth, Wichern \& Ratcliff 2000:29) aangesien dit elemente verteenwoordig vanuit die narratiewe benadering, die kognitiewe benadering, asook die sisteemteorie.

\section{Ontrafel knope in die gesin}

Selekman (2010) verwys na tipiese dilemmas binne die gesin van 'n self-snyer as 'knope' in so 'n gesinstruktuur, die uitdaging aan die berader is om hierdie knope te ontrafel. In die verband gee hy die volgende twee belangrike riglyne.

\section{Help die gesin om deur ontkenning te breek}

Aangesien talle self-mutilerende jongmense hulle brand- en snymerke verberg vir ouers en ander volwassenes deur die dra van langmouhemde en langbroeke en ook relatief goed funksioneer in meeste areas van hulle lewens, sou ouers onder die indruk kon wees dat daar nie noodwendig 'n probleem is nie. In die teenwoordigheid van die kind moet die ouers gevolglik met die konkrete feite gekonfronteer word.

\section{Belangrike terapeutiese take om te verrig}

Selekman (2010) wys ook op die volgende belangrike terapeutiese take om te verrig betreffende die gesin van 'n self-mutilerende adolessent:

- Konfronteer alle aftakelende gesinsinteraksies gekoppel aan tradisionele patriargale sosialiseringspraktyke (pa het die finale sê en duld geen ander opinies nie).

- Skep 'n veilige terapeutiese klimaat waarin toestemming verleen word aan die self-mutilerende adolessent om hulle woede of enige ander onaangename gedagtes of 
negatiewe emosies wat hulle sou ervaar in spesifieke gesinsverhoudinge of enige ander sosiale konteks te mag eksternaliseer: "replacing impulsive action with "words" is one of the main keys to successful treatment with self-harming adolescents' (Selekman 2010).

Sim et al. (2009:88) voeg in die verband ook die volgende by: 'It is likely that teaching parents ways of communicating, understanding and guiding children's emotional behavior would promote healthy emotional and psychological development.'

\section{Eksploreer oplossings en raad vanuit die verlede}

Dit is belangrik om saam met die adolessent alle vorige suksesse te evalueer. Evalueer situasies waar hulle dit reggekry het om wel hulle gemoedstemming te beheer en stresvolle situasies te oorkom. Identifiseer dan beginsels wat toegepas kan word op die huidige situasie (Selekman 2010).

\section{Die belangrikheid van neutrale nie-bedreigende gesprekke}

Clark en Henslin (2007) gee die volgende praktiese raad:

Wisdom resists over-interpretation. You can best honor those you love by observing the signs, praying diligently, opening the door for others to share their struggles, and confronting behaviors when needed. (bl. 124)

Indien dit sou blyk dat iemand self-mutilering toepas of weer daarin verval het, is die beste raad om betrokke te raak deur middel van neutrale nie-bedreigende gesprekke. Indien daar 'n noue emosionele band met die betrokke persoon is, gaan dit uiteraard moeilik wees, maar eise en woedende reaksies gaan nie die gewenste reaksie ontlok by 'n self-mutileerder wat emosioneel verwond is nie. Lax (2010) verwoord dieselfde beginsel soos volg:

Telling someone to stop self-harming is likely to make the situation worse, as a person cannot even begin to think about stopping until they have other ways to deal with their feelings. (bl. 5)

Hierdie tipe gesprekke vereis 'n sagtheid (gentleness) en baie geduld. Op hierdie wyse kan die berader deel word van 'n gesonde en langtermyn-herstelproses. Binne dieselfde verband maak Gregston (2006) die volgende belangrike stelling:

The source of the problem becomes the main issue. The main issue, which is not the cutting, must remain the main issue. And parents have got to quit thinking that the band-aid of 'just stop doing that' is going to 'fix' anything. (bl. 20)

\section{Onttrekkingsimptome}

Wanneer gewoonte-self-mutileerders op hulle eie sou probeer om die proses te termineer, sou hulle onttrekkingsimptome kon ervaar soortgelyk aan die ervaring van 'n rehabiliterende dwelmverslaafde. Die aksie van sny of brand het telkens daartoe gelei dat 'n pynstillende chemiese bestanddeel afgeskei is waaraan die persoon uiteindelik verslaaf geraak het. Die gevolg hiervan kan onder meer aggressiewe en hiperaktiewe gedrag wees, asook oormatige angs wat kan dreig om hulle emosioneel te oorweldig. Talle gee uiteindelik weer toe aan hierdie emosies en dit kan selfs tot ' $\mathrm{n}$ meer aggressiewe siklus van selfbenadelende gedrag lei (Clark \& Henslin 2007:100; Penner 2008:93).

\section{Die belangrikheid van elkeen se verhaal}

Volgens Selekman (2002:18) is daar drie sterk kragte wat bydra tot die ontwikkeling en handhawing van aftakelende gesinsinteraksies, asook tot die stilmaak van veral meisies wat self-mutilering toepas: a) die verkeerde hantering van woede; b) sterk patriargale en kulturele voorskrifte betreffende die wyse waarop 'n vrou behoort te dink en op te tree; en c) gesinsgeheime. Teen hierdie agtergrond is dit van kritiese belang dat beraders daarop sal fokus om die selfmutileerders se 'stem' hoorbaar te maak in sessies met die gesin (Scholtz \& Fiedeldey 1994:143).

When an individual is feeling a strong sense of hopelessness, a lack of power, and relatively little control in his or her family, cutting, burning, substance abuse and eating disorders can give the person a false sense of being in control. (Selekman 2002:18)

\section{Werk die verlede deur}

Clark en Henslin (2007:74) haal navorsing aan wat daarop dui dat ongeveer $50 \%$ van self-mutileerders rapporteer dat hulle as kind misbruik is, hetsy fisies en/of seksueel (Yip 2006:143). Wat persentasies betref, gaan Holm en Severinsson (2008:32) selfs nog verder met die volgende stelling: 'Up to $80 \%$ of individuals experience emotional pain that is an adaptive response to repetitive traumatic experiences in childhood.'

Herhaaldelike misbruik, veral deur diegene wat vertrou word, impliseer emosionele vernietiging van die hoogste orde. Clark en Henslin beskryf dit as sielsmoord. Dit is dus uiters belangrik dat die pyn van die verlede tydens die terapeutiese proses aan die orde kom.

\section{Identifisering van enige onverwerkte seksuele trauma}

'n Belangrike komponent van die eksplorering van die verlede is om veral enige onverwerkte seksuele trauma te identifiseer (Yip 2006:141).

\section{Vra uit na hoe alles begin het}

Vra die persoon wat self-mutilering toepas, om te vertel hoe alles begin het. Vra in watter mate hierdie hele aangeleentheid soms emosioneel oorweldigend is en ook watter gedagtes en gevoelens betrokke was by die eerste daad, en ook telkens daarna. Daar kan spesifiek gevra word of daar 'n sekere tyd van die dag of spesifieke situasies is wat gevoelens aktiveer om self-mutilering toe te pas, en ook of daar bepaalde persone is wat hierdie emosies telkens sneller.

Hou ook deurgaans in gedagte dat dit aanvanklik angswekkend mag wees vir iemand wat vir 'n tyd lank hierdie praktyk beoefen het om te dink dat daar voortaan sonder hierdie moontlikheid voortgegaan sal moet word (Kern 2007:89). 


\section{Vervang leuens met waarheid}

Die self-mutileerder is dikwels verward as gevolg van negatiewe veronderstellings en leuens (Kern 2007:67; Penner 2008:60). In die lig hiervan interpreteer die ontwikkelende denke van die adolessent hulle persoonlike geskiedenis en kom tot gevolgtrekkings met betrekking tot hulle persoonlike identiteit. Omdat liefdevolle en objektiewe volwassenes dikwels ook ontbreek in die lewe van talle adolessente, word sulke negatiewe veronderstellings selde bevraagteken. Die gevolg is dat sulke jongmense krampagtig aan sulke veronderstelling kan vasklou, aangesien dit 'n verklaring bied met betrekking tot gebeure van die verlede. Luister na Mandy se pynvolle verduideliking van hierdie soort ervaring:

Life works for me as long as I view myself as a worthless piece of crap.

I am useless, I am nothing. I am unlovable, and that's why my mom

drank when I was little. I am a whore so I was sexually abused when

I was seven. I am a slut which is why I was raped when I was 13.

(Penner 2008:60)

Binne die denke van 'n tiener is skaamte (shame) gelykstaande aan foutief en disfunksioneel. Skuldgevoelens het gewoonlik te doen met dít wat die persoon gedoen het, terwyl skaamte verband hou met wie die persoon is. Die wanhoop wat voortspruit uit die oortuiging dat daar niemand is wat omgee nie, versterk soveel te meer die greep van self-mutilerende gedrag (Bradshaw 2005:144).

Solank die negatiwiteit rondom die selfbeeld in plek is, vervul dit slegs een funksie, naamlik om te kompenseer vir die tekortkominge deur maskers en kamoeflering, soos wat dit die geval is met jongmense wat hulle eie liggame mutileer. Die gevoelens van selfveragting word na binne gekeer en die emosies word geventileer deur middel van self-toegediende wonde.

\section{Konfronteer die leuens}

Omdat hierdie leuens heel dikwels gegenereer is binne teleurstellende verhoudings, is dit nodig dat hulle gekonfronteer en uitgedaag word deur liefdevolle, konsekwente en toegewyde verhoudings. Die mees effektiewe wyse waarop daar reageer kan word teenoor jongmense wat sulke verdraaide veronderstellings omtrent hulle eie identiteit het, is om hulle te help om die waarheid van hulle identiteit in Christus te ontdek en te omhels (McDonald 1995:209; Thurman 1999:77; Kruger 2010:158).

\section{Vernuwing van denke}

Vernuwing van denke impliseer vir jongmense wat hulleself mutileer dat hulle leer om te glo wat God van hulle sê eerder as die gevolgtrekkings wat hulle van hulleself gemaak het (vgl. Rom 12:2). Dit gaan onwillekeurig ook daartoe lei dat hulle die verdraaide interpretasies en leuens eenkant skuif - dit wat klaarblyklik sin gemaak het te midde van verwarrende gebeure en pynvolle omstandighede.

Dit alles gaan 'n geweldige risiko inhou, aangesien die prysgewing van die ou veronderstellings daadwerklik die prysgewing van kontrole en beheer gaan impliseer. Kontrole en beheer is een van die sentrale temas betreffende die motivering agter self-mutilerende gedrag: om pyn te beheer; om andere se sieninge te beheer; om verhoudinge te beheer; om die toekoms te beheer en om die eie liggaam te beheer (Kern 2007:129).

\section{Hantering van onbevraagtekende veronderstellings en leuens}

Penner (2008:114) bespreek die volgende voorbeelde van tipiese leuens wat oor die algemeen aanvaar word as die waarheid deur die emosioneel verwonde persoon, aangesien dit by geen geleentheid in die verlede bevraagteken is nie.

My keuse beïnvloed niemand anders nie: Die leuen dat selfmutilering niemand anders raak nie, word uitgedaag deur die waarheid van Paulus se woorde in 1 Korintiërs 12:25:

... sodat daar nie verdeeldheid in die liggaam sou wees nie, maar dat die lede gelyke sorg vir mekaar dra. As een lid ly, ly al die lede saam; en as een lid geëer word, is al die lede saam bly.

Dit is my liggaam en ek kan daarmee doen wat ek wil: Selfmutileerders verklaar eintlik deur hulle gedrag dat hulle hulle eie liggame teruggeneem het. Om te verklaar, 'Hierdie is myne!' skep ten minste die illusie van mag en veiligheid (Clark \& Henslin 2007:45; Holm \& Severinsson 2010:55).

Hierteenoor staan egter die uitspraak in 1 Korintiërs 6:19-20:

Of besef julle nie dat julle liggaam ' $n$ tempel van die Heilige Gees is nie? ... julle behoort nie aan julleself nie: julle is gekoop, en die prys is betaal. Julle moet God dus in julle liggaam verheerlik.

Indien ek die self-mutilering sou termineer, sal ek geen doeltreffende manier hê om my pyn te hanteer nie: Op 'n punt soos hierdie is die berader se rol nie om 'n alternatief voor te stel nie, maar om eerder 'n verhouding aan te bied aan jongmense wat huiwerig is en hulleself op ' $n$ afstand hou, aangesien hulle vertroue in die verlede telkens verraai is (Selekman 2002:183; Gregston 2006:48).

Indien ek nie myself sou mutileer nie, sal mense geen idee hê van hoeveel pyn ek aan die binnekant het nie: 'n Aspek soos hierdie bied aan die berader die uitdaging om 'n kwaliteitverhouding met sulke jongmense te ontwikkel. Volle erkenning sal gegee moet word aan hulle behoefte aan verhoudings, terwyl die metodes waardeur hulle dit probeer bereik egter uitgedaag moet word.

In reaksie op die leuen dat niemand hulle pyn sal raaksien tensy hulle hulleself mutileer nie, moet daar aan sulke verwonde jongmense die waarheid gebied word van 'n gemeenskap wat sensitief is vir hulle behoeftes en ook daarop gefokus is om hulle op te bou (Kern 2007:75; Clark \& Henslin 2007:56).

Ek moet sny want dan kom mense nie naby my om my seer te maak nie: Die enigste manier waarop hierdie leuen wat mense op 'n afstand probeer hou, sinvol uitgedaag kan word, is weereens deur gesonde verhoudings. Om bloot daaroor te praat, gaan geen verskil maak nie. Om daaroor te preek, gaan hulle nie oortuig nie. Inteendeel, hierdie jongmense sal moet ervaar dat iemand regtig vir hulle omgee en vir hulle lief is (Brown, Williams \& Collins 2007:798). 
Ek het steeds skuldgevoelens en kan myself nooit genoeg straf nie: Dit is 'n groot uitdaging om self-mutileerders te help om ware skuldgevoelens te onderskei van die valse skuldgevoelens wat hulle onregmatiglik op hulleself geplaas het. Sulke jongmense is dikwels geneig om hulleself te straf vir wie hulle is, eerder as vir wat hulle gedoen het. Penner (2008:119) sê dat wanneer hy die woorde lelik, stupid en verwerplik uitgekerf sien op 'n meisie se arm en sy hom vertel dat sy haarself sny omdat hierdie woorde waar is van haar, dan besef hy dat sy haar behoefte aan vergifnis (wat vryheid van skuldgevoelens meebring) verwar het met haar behoefte aan aanvaarding (wat ware hoop en heling meebring). Die goeie nuus van die Evangelie is dat sy ten volle aanvaar en ook ten volle vergewe is (Clark \& Henslin 2007:132; Hicks \& Hinck 2008:411; Holm \& Severinsson 2010:55).

Indien ek self-mutilering sou prysgee, kan ek moontlik uiteindelik iets erger aanvang: Net soos sommige van die ander leuens is hierdie een ook gewortel in vrees. Die spesifieke vrees by talle self-mutileerders is dat indien hulle die self-mutilerende gedrag sou beëindig, dit sou kon lei tot selfmoord. Hulle betaal gevolglik 'n groot prys ten einde selfmoord te probeer verhoed, en in hierdie opsig moet daar erkenning gegee word aan hulle volharding en uithouvermoë. Wanneer hierdie leuen gekonfronteer word, is dit gevolglik belangrik om spesifiek erkenning te gee aan hierdie jongmens se begeerte om aan die lewe te bly. Hulle moet ook gewys word op die belangrikheid van hierdie sterk punt wanneer hulle alternatiewe en minder destruktiewe wyses van oorlewing gaan eksploreer (Pattison \& Kahan 1983:867; Whitlock 2010).

\section{Die rol van vergifnis}

Om ander te vergewe, kan vir die self-mutileerder 'n baie moeilike saak wees (Clark \& Henslin 2007:190). Hier moet in gedagte gehou word dat vergifnis nie noodwendig jare se pyn uitkanselleer nie. Die persoon moet ook toegelaat word om te praat oor die seer terwyl daar deur vergifnis gewerk word. Vergifnis is inderdaad ' $n$ proses.

Wanneer dit sou blyk dat die proses van vergifnis geneig is om sekere oorweldigende emosies te sneller, is dit raadsaam om dit eerder saam met ' $n$ berader te eksploreer, wat begrip het vir die proses (Kern 2007:171; Penner 2008:95).

\section{Die rol van Nagmaal}

Clark en Henslin (2007:194) verwys na die geval van 'n self-mutileerder, Natalie, wat 'n sewe jaar-lange stryd met self-sny gehad het. 'n Belangrike komponent van haar pad na genesing was die tyd wat sy bestee het aan haar geloof en geestelike transformasie. As deel hiervan het sy die besondere genesingskrag van Christus se inkarnasie ervaar deur die gereelde gebruik van Nagmaal. Sy beskryf haar ervaring soos volg:

Sometimes the only thing that got me through the week was the Eucharist on Sunday and the symbolism of deep truths there. Taking Christ's body into mine and acknowledging that my body is holy now and belongs to God, that I am in fact a part of the body of Christ, meant so much. It made me realize that when I harm my body I am harming the body of Christ. The wine symbolizing Christ's blood coming inside me and cleansing every part of me reminded me it was done. I am clean, I am forgiven, and there is nothing else I have to prove. (Clark \& Henslin 2007:194)

\section{Gebed en meditasie}

Gebed en meditasie kan 'n belangrike fasiliterende rol vervul met betrekking tot die innerlike vrede wat God vir die mens begeer. Self-mutileerders kan bemagtig word in die aanleer en effektiewe beoefening van hierdie geestelike dissiplines (Clark \& Henslin 2007:193).

\section{Die rol van die kerk}

Christen-jongmense wat worstel met self-mutilering ervaar' $n$ oorweldigende skuldgevoel as gevolg van hulle klaarblyklike onvermoë om God se genesende krag vir hulleself toe te eien. Dit wil voorkom asof God in staat is om al die ander persone te help om in oorwinning te leef, terwyl hulle slegs 'n reeks mislukkings beleef. Penner (2008) verwoord Mike se gevoelens in die verband soos volg:

I look around me during the worship time at youth group. Everyone seems so into it with their hands raised and big smiles on their faces. I couldn't raise my hands even if I felt like it, cuz then everybody'd just be staring at my ugly arms. We sing songs about how God can take away our pain and heal our hurts, but my guess is that not one of those goody-goodies has ever had any real pain or hurt in their life. (bl. 70)

Wanneer lidmate worstel met sodanige gevoelens van skuld en vervreemding en daar by kerklike leierskap ook nog die onvermoë bestaan om gepas te kan reageer op self-mutilerende gedrag, lei dit tot ' $n$ groep gelowiges wat desperaat alleen is in hulle pyn.

Volgens Kern (2007:34) is daar 'n groot behoefte aan meer gesprekke, veral ook in die kerk betreffende die rol van pyn in mense se lewens. Aansluitend hierby doen Clark en Henslin (2007:150) 'n beroep op Christen-beraders om in ' $n$ groter mate die belangrikheid van geestelike heling te modelleer.

\section{Slot}

Die verskynsel van self-mutilering by jongmense blyk ' $n$ groeiende probleem te word. Dit gaan duidelik nie primêr om 'n poging tot selfmoord nie, maar eerder om 'n noodkreet betreffende diep innerlike letsels en wonde. Aan die pastorale berader sowel as die kerk bied dit ' $n$ besondere uitdaging. Daar sal indringend kennis geneem moet word van basiese vertrekpunte en houdings wat bevorderlik kan wees vir heling en genesing in die lewens van emosioneel gekwetste en verwarde jongmense.

\section{Erkenning Mededingende belange}

Die outeur verklaar dat hy geen finansiële of persoonlike verbintenis het met enige party wat hom nadelig kon beïnvloed in die skryf van hierdie artikel nie. 


\section{Literatuurverwysings}

Aizenman, M. \& Jensen, M.A.C., 2007, 'Speaking through the body: The incidence of self-injury, piercing, and tattooing among college students', Journal of College Counseling 10, 27-43. http://dx.doi.org/10.1002/j.2161-1882.2007.tb00004.x

American Psychiatric Association (APA), 2000, Diagnostic and Statistical Manual of Mental Disorders, 4th edn., American Psychiatric Association, Washington, DC.

Bradshaw, J., 2005, Healing the shame that binds you, Health Communications, Deerfield Beach, FL.

Brown, S.A., Williams, K. \& Collins, A., 2007, 'Past and recent deliberate self-harm: Emotion and coping strategy differences', Journal of Clinical Psychology 63(9), 791-803. http://dx.doi.org/10.1002/jclp.20380, PMid:17674395

Clark, J. \& Henslin, E., 2007, Inside a cutter's mind , THINK, NavPress, Colorado Springs, CO.

Freeman, H., 2003, 'Girls who cut', The Guardian, 02 Sept. 2003, viewed 25 June 2006 , from http://www.guardian.co.uk/health/story/0,3605,1033775,00.html

Gratz, K.L. \& Roemer, L., 2008, 'The relationship between emotion dysregulation and deliberate self-harm among female undergraduate students at an urban commuter University', Cognitive Behavior Therapy 37(1), 14-25. http://dx.doi org/10.1080/16506070701819524, PMid:18365795

Gregston, M., 2006, The phenomenon of cutting, Heartlight Ministries, Hallsville, TX.

Harmless, 2010a, Advice for young people, Harmless is a user led organization that provides a range of services about self harm (Factsheet 1), viewed 14 Sept. 2010, from http://www.harmless.org.uk/downloads.php?cat id $=1$

Harmless, 2010b, Advice for friends and family, Harmless is a user led organization that provides a range of services about self harm (Factsheet 2), viewed 14 Sept. 2010, from http://www.harmless.org.uk/downloads.php?cat_id=1

Hemfelt, R., Minirth, F. \& Meier, P., 2003, Love is a choice, Thomas Nelson, Nashville, TN.

Hicks, K.M. \& Hinck, S.M., 2008, 'Concept analysis of self-mutilation', Journal of Advanced Nursing 64(4), 408-413. http://dx.doi.org/10.1111/j.1365-2648.2008. 04822.x, PMid:19006819

Holm, A.L. \& Severinsson, E., 2008, 'The emotional pain and distress of borderline personality disorder: A review of the literature', International Journal of Mental Health Nursing 17, 27-35. http://dx.doi.org/10.1111/j.1447-0349.2007.00508.x PMid:18211401

Holm, A.L. \& Severinsson, E., 2010, 'Desire to survive emotional pain related to selfharm: a Norwegian hermeneutic study', Nursing and Health Sciences 12, 52-57. harm: a Norwegian hermeneutic study', Nursing and Health Sciences
http://dx.doi.org/10.1111/j.1442-2018.2009.00485.x, PMid:20487326

Horning, G., 2010, 'Cutting', Cosmopolitan October, 107-108.

Kern, J., 2007, Scars that wound: Scars that heal, Standard Publishing, Cincinnati, $\mathrm{OH}$.

Kruger, R., 2010, 'Pastorale begeleiding van die emosioneel verwonde person met betrekking tot geïnternaliseerde leuens', PhD Proefskrif, Departement Praktiese Teologie, Potchefstroom, Noordwes-Universiteit.

Lax, R., 2010, 'Self-harm: Looking behind the injury', Practice Nurse 39(4), 5.
Levenkron, S., 1999, Cutting: Understanding and overcoming self-mutilation, W.W. Norton, New York City.

McDonald, A.N., 1995, Repressed memories, Can you trust them?, Fleming H. Revell, Grand Rapids, MI.

Meier, P.D., Minirth, F.B., Wichern, F.B. \& Ratcliff, D.E., 2000, Introduction to psychology and counselling, Christian perspectives and applications, Baker Books, Grand Rapids, MI.

Minirth, B. \& Byrd, W., 1994, Christian psychiatry, Fleming, H. Revell, Grand Rapids, MI.

Pattison, E.M. \& Kahan, J., 1983, 'The deliberate self-harm syndrome', The American Journal for Psychiatry 140(7), 867-872.

Penner, M., 2008, Hope and healing for kids who cut, Zondervan, Grand Rapids.

Ryan, K., Allen Heath, M., Fischer, L. \& Young, E.L., 2008, 'Superficial self-harm: Perspectives of young women who hurt themselves', Journal of Mental Health Counseling 30(3), 237-254.

Scholtz, J.G. \& Fiedeldey, A.C., 1994, 'Die belewenis van self-mutilasie by Grenspersoonlikheidsversteuring', South African Journal of Psychology 24(3), 138-144.

Selekman, M.D., 2002, Living on the razor's edge, W.W. Norton, New York.

Selekman, M.D., 2010, 'Helping selfharming students', Educational Leadership 67(4), 49-53.

Shamos, J., 2007, 'Body crimes', African Journal of Psychiatry November, 255-256.

Sim, L., Adrian, M., Zeman, J., Cassano, M. \& Friedrich, W.N., 2009, 'Adolescent deliberate self-harm: linkages to emotion regulation and family emotional climate', Journal of Research on Adolescence 19(1), 75-91. http://dx.doi. org/10.1111/j.1532-7795.2009.00582.x

Strong, M., 1998, A bright red scream: Self-mutilation and the language of pain, Viking, New York City.

Swannell, S., Martin, G., Scott, J., Gibbons, M. \& Gifford, S., 2008, 'Motivations for self-injury in an adolescent inpatient population: Development of a self-report measure', Australasian Psychiatry 16(2), 98-103. http://dx.doi.org/10.1080/ measure, Australasian Psychiatry 16
10398560701636955, PMid:18335365

Swenson, C.R., 1999, 'Book reviews of "A bright red scream: Self-mutilation and the language of pain", by Marilee Strong, and "Cutting: Understanding and overcoming self-mutilation", S. Levenkron (reviewer), Psychiatric Services 50(9), September, 1234-1235.

Thurman, C., 1999, The lies we believe, Thomas Nelson Publishers, Nashville.

Welsh, P., 2004, Students' scars point to emotional pain, USA Today, 28 June, viewed 27 October 2010, from http://www.usatoday.com/news/opinion/editorials/200406-27-oplede_x.htm

Whitlock, J., 2010, What do we know about self-injury? (Fact sheet) Cornell research program on self-injurious behavior in adolescents and young adults, viewed 11 October 2010, from http://www.crpsib.com/whatissi.asp

Yip, K., 2006, 'A strengths perspective in working with an adolescent with self-cutting Behaviors', Child and Adolescent Social Work Journal 23(2), 134-146. http:// dx.doi.org/10.1007/s10560-005-0043-4 